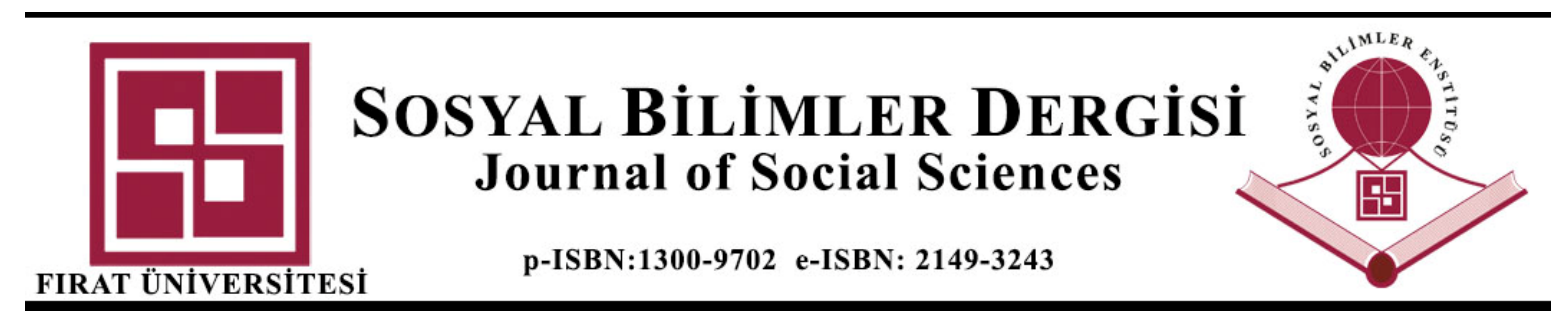

\title{
“BİR TEREDDÜDÜN ROMANI"NDA POSTMODERN ROMAN UNSURLARI
}

\section{Elements of the Postmodern Novel in "Bir Tereddüdün Romanı"}

\section{Nilüfer AKA ERDEM ${ }^{1}$}

${ }^{1}$ Dr. Öğr. Üyesi, Ankara Hacı Bayram Veli Üniversitesi, Edebiyat Fakültesi, Türk Dili ve Edebiyatı Bölümü, Ankara, nilufer.akaerdem@hbv.edu.tr,orcid.org/0000-0001-7379-3468

Araştırma Makalesi/Research Article

\begin{tabular}{ll}
\hline Makale Bilgisi & ÖZ \\
Geliş/Received: & Türk ve Batı edebiyatındaki edebît türlerin gelişimi üzerine kritikler ve incelemeler yapan \\
08.07 .2021 & Peyami Safa, romanda teknik konusunda farklılıklara ve yeniliklere açık bir anlayışa \\
Kabul/Accepted: & sahiptir. Roman türü konusunda teorisyen misali değerlendirmeleri olan yazar \\
25.08 .2021 & "mükemmel”e ulaşmak gayesiyle çeşitli teknikleri dener. Romanın ulusal ve uluslararası \\
DOI: & bağlamda geçirdiği dönüşümleri, aşamaları inceleyen Safa'nın Bir Tereddüdün Romanı adlı \\
$10.18069 / f i r a t s b e d .967568$ & eserinde kurguyu şekillendiren teknikler ve karakterlerin konumu noktasında postmodern \\
& romana özgü nitelikleri kullandığı dikkat çeker. Modern ve postmodern anlayışın birbiri \\
& içinde yer aldığı bir dönemde kaleme alınan romanın modernden postmoderne geçişte kritik \\
& evreyi yansın bir geçiş dönemi ürünü olduğu söylenebilir. Romanda üst kurmaca, \\
& metinlerarasılık yönteminin ve çoğul bakış açısının kullanılması, yazar-okur-metin \\
& ilişkisinin roman yazma sürecine dâhil edilmesi, yazarın okuru metne dâhil ederek onunla \\
Anahtar Kelimeler & konuşması ve roman içerisinde başka bir romanın yazılma sürecinin yer alarak ana metnin \\
Peyami Safa, postmodern & kurgusunu yönlendirmesi gibi teknikler postmodern romanın özellikleridir. Bu çalışmada, \\
novel, narrative technicues, & Bir Tereddüdün Romanı adlı eserin yapı ve içerik unsurlarının postmodern romanın \\
postmodern subject & özellikleriyle benzerliklerinin çözümlenmesi ve yorumlanması amaçlanmaktadır. \\
\hline
\end{tabular}

\section{ABSTRACT}

Keywords

Peyami Safa, postmodern novel, narrative technicues, postmodern subject
Peyami Safa, who carried out critiques and studies on the development of literary genres in Turkish and Western literature, had an approach that was open to differences and innovations in terms of technique in novels. The writer, who had theoretician-like comments on the novel genre, tried various techniques for the purpose of reaching "perfection". It is seen that Peyami Safa examined the transformation and stages of the novel in the national and international contexts and used qualities unique to the postmodern novel at the point of techniques that shaped the construct and the positions of the characters in his work titled Bir Tereddüdün Romanı [the Novel of a Hesitation]. It may be argued that this novel that was written in a period where the modern and postmodern approaches were intertwined is a transition-period product that reflects a critical stage from the transition to the modern to the postmodern. In the novel, techniques like the use of metafiction, the method of intertextuality and a pluralistic point of view, the inclusion of the writer-reader-text relationship in the writing process, the writer's inclusion of the reader into the text and his conversation with the reader and the fact that the writing process of another novel is included in the novel and directs the plot of the novel are characteristics of the postmodern novel. In this study, it is aimed to analyze and interpret the similarities of the structural and content-related elements of the work titled Bir Tereddüdün Romanı to the properties of the postmodern novel.

Atıf/Citation: Aka Erdem, N. (2021). "Bir Tereddüdün Romanı"nda Postmodern Roman Unsurları, Fırat Üniversitesi Sosyal Bilimler Dergisi,31, 3(1161-1170).

Sorumlu yazar/Corresponding author: Nilüfer AKA ERDEM, nilüfer.akaerdem@hbv.edu.tr 


\section{Giriș}

Edebî eseri tasnif etmek, yazarın özerk deneyimine ilişkin durumu bertaraf edip eseri, yazarı, yazım sürecini rafa kaldırmakla eşdeğerdir. Metnin sonsuz anlamlandırma olanaklarını sınırlamaktır. Modernizmin kategorize eden, sınıflandıran, düzene sokan, tutarlı görünüşler arayan, kurucu, bilen, merkezdeki, seçkinci anlayışına karşılık; roman türü özelinde okuru dikkate alan, önemseyen alımlama estetiği (Özbek, 2005: 3) metnin yorumu noktasında sonsuz olanak sunmaktadır. Okurun metne nüfuz etmesiyle yazar-okur arasındaki etkileşim, yazın alanında süreç boyunca dinamiktir. Dolayısıyla "yapıtlar birden çok anlamlar içerirler; çok katmanlıdirlar; bir veya birkaç perspektif onların çözümlenmesi için yeterli olmaz" (Özbek, 2005: 3). Metnin çok anlamlılı̆̆ her okurun metne bakışıyla ilişkili olarak yenilenir, değişir, her bakışta yeniden inşa edilir. Yazar-okur-metin ilişkisinde bireysel farkındalık ve algılama "an"ları okurun imgelemine yansıtıcı olarak ortaklık eder. Bu durum, Gadamer'in metin okuma eylemini okurla metin arasındaki "hermeneutik diyalog" biçiminde adlandırması ile ilişkilidir. Okurun yaptı̆̆ yorum, "şimdi”"nin bakış açısıyla olduğu için yeniden yorumlamadır. Gadamer yine bunu "Ufukların Kesişmesi" olarak irdeler (Yavuz, 2010: 18). Okurla metnin ufku, okuma sürecinde kesişir ve bu kesişmeler neticesinde sayısız anlamlandırma biçimleri, şekilleri ortaya çıkar. Farklılıkların birleşmesi, bir ruhun ortaya koyduğundan başka bir ruhun nemalanmasıyla gerçekleşir. Bu anlamda Peyami Safa'nın 1933 yılında yayımlanan Bir Tereddüdün Romanı metninin sunduğu söylem dünyası, her okurun alımlama kabiliyetiyle değerlendirilmelidir. Romanı "Avrupalı bir edebiyat" ürünü olarak gören Cahit Sttkı Taranc1; “Bir Tereddüdün Romanı'nı anlayabilmek için iyi bir kültüre ihtiyaç vardır" der (Taranc1, 1940: 21). Okurun metne yönelik hazırbulunuşluğunun olması gerektiği düşüncesi, romanın her okurun birikimine göre yorumlanabileceğinin ifadesidir. Bu noktada Bir Tereddüdün Romanı'nın başkarakteri Muharrir; "Ben her kitabımin her sayfasını, her satırın ve her kelimesini okurken binlerce karimin ayrl ayrt yanında bulunmak isterdim; yanında değil, hattâ ruhunun içinde" (Safa, 2019: 39) sözleriyle eserlerinin binlerce okuru tarafından nasıl yorumlandığını merak ettiğini dile getirir. Böylece Muharrir, okurun alımlama kabiliyetine göre bir metnin anlamının çoğaltılabilirliğine işaret etmektedir. $\mathrm{Bu}$ anlamda "Bir metin, yorumcunun sonsuz iç bağlantılar keşfedebileceği açık-uçlu bir evrendir"(Eco, 2003: 49) ile "her okur kendi anlamını üretir ve bu yaratıcı edimdir" (Ecevit, 2011: 80) ilkeleri metin-okur ilişkisi bağlamında romandaki en net görünümüne kavuşmuş olur.

Yazın yaşamını zorlu hayat mücadelesi içinde sürdüren Safa, çeşitli yazı türlerinde eser vermiştir. Kendi kendini yetiştirmesi, aynı zamanda onun birçok alanda kendi çabasıyla derinleşmesini sağlamıştır. Dolayısıyla Safa, "kariden de bilmukabele sabırll bir dikkat, etraflı ve hazmedilmiş bir kültür, süzülmüs bir zevk ve derin bir düşünme kabiliyeti talep eder" (Taranc1, 1940: 9). Edebî türlerin Türk edebiyatı ve Batı edebiyatındaki gelişim safhaları üzerine kritikler yapan Safa, romanda teknik konusunda yeniliklere açık bir yazardır ve eserlerinde çeşitli teknikleri denemiştir. Her ne kadar "1980'li yıllara kadar, hem romancı hem okur için, romanda ne anlatıldı̆̆gl; nasıl anlatıldığından önemli olduğu" (Narlı, 2012: 218) görüşü kabul edilse de bu Peyami Safa için geçerli bir çıkarım değildir. Roman tekniği üzerine düşünen Safa, romanda "umumi bir kaideden" söz edilemeyeceği görüşüyle özellikle I. Dünya Savaşı'ndan sonra "teknik anarşi" sininin olduğunu söyler. Teknik üzerine çok kafa yorduğunu, Fransız, İngiliz, Alman ve Rus romanlarını okuduğunu belirten ve eserlerinde de uygulamaya girişen Safa, "mükemmel" bir tekniğe ulaşamadığını ifade eder (Safa, 2012: 215). Aynı konuda Resimli Ay dergisinde 1939 yılında yayımlanan yazısında Batı'da romanın hasta olduğunu ve bu buhranın bir karmaşaya sebep olduğunu şu sözlerle ifade eder; "Bu buhran, romana dair pek çok şey yazılmasına ve hiçbir karar verilememesine sebep oluyor. Orada roman hastadır. Ve kırk dereceyi geçen bir nöbeti var" (Safa, 2012: 202-203). Yazarın sözünü ettiği romanın yapı ve içerik unsurlarına ilişkin sorgulamaların yapıldığı 20.yüzyılın ilk yarısı, ikinci yarısında yeni roman ve devamında postmodern roman olarak tarif edilecek bir dönüşümün sinyallerinin verildiği döneme denk gelmektedir.

Siyasi, ekonomik, toplumsal, felsefi, sanatsal alanlardaki yerleşik düzenin yıkılması ve aydınlanma düşüncesinin temel dinamiklerinin insanlı̆ğ getirdiği huzursuzluk ve yabancılaşma ortamına eleştiri, edebî metinlerde de karşıllı̆̆nı bulur. Modernizmi eleştirirken onun içinde var olan postmodernizm, yazınsal birikimde "edebiyat alanindan gelen bir başkaldırı" (Ecevit, 2011: 67) olarak nitelenir. Dolayısıyla postmodern dönem için roman türüne özgü geleneksel addedilen yerleşik kurgusal ve içeriksel özellikler önemini yitirir. Postmodern anlatı, modernleşmenin karşı çıktığı geleneksele karşı değildir, bilakis gelenekseli kullanır. Fakat bu anlatı türü, modernleşmenin dondurduğu, kategorizeleştirerek mutlak addettiği değerleri 
altüst eder, karmaşıklaştırır. Gerçeklik, anlam, kimlik, birey, idealleştirilen bütün değerler, gelenek, akıl, bilim, hegemonya, mutlaklık, tutarlılık, bütünlük, düzenli oluş, özgürlük, mekân, zaman, ahlak gibi birçok kavram hayatı ve bilim dünyasını ilgilendiren yönleriyle kritik edilir. Roman türünde bu eleştirel tutumun yansıması gerek içerik gerek kurgusal anlamda görülür. Postmodern romanın özellikleri olarak addedilen "üst kurmaca, metinlerarasıllk, polisiye-gerilim-tarihe yönelme" (Sazyek, 2017: 600) teknikleri, anlatı dünyasında sinırsız özgürlükle karmaşıklaştırılır ve nihayetinde kurguda bir oyun alanı oluşturulur.

Roman tekniği konusunda teorisyen gibi kritikler yapan Safa, eserlerinde de elde ettiği birikimi deneyimlemeye girişir. Safa, bilinçli olarak roman kurgusunda yenilik yaptığını şu cümlelerle belirtir: "Benim her romanımda ötekilere nispetle böyle bir başkalık ve ayrllık vardır. Çünkü her birinde kendimi aşmak ve çok aradığım "mükemmel"e ulaşmak istedim. Tek imkân içinde kaliplanmak ve kendi kendimi tekrarlamaktansa saylsı imkânları denemeye çalı̧̧mak benim yaratma huyumdur" (Baydar, 2015: 256). Yazarın bu ifadeleri, postmodern anlatı dünyasının sürekli yeniden üretimi, yenilenmeyi, değişikliği, esnekliği, dinamik oluşu önceleyen yönünü imlemektedir.

Bir Tereddüdün Romanı içerisinde bulunan Bir Adamın Hayatı adlı romanının Muharrir'i ve başkişisi roman tekniği üzerine görüşler sunar; “ 'teknik' denilen şey öyle bir meleke ve itiyat yekûnudur ki, nihayet gayrı şuura ait faaliyetler arasinda girer ve spontane bir tarzda meydana gelen sanat eseri, kendi tekniğini de beraber taşır. En büyük hatamız, tekniği, yaratıc ilcalarımıza inzimam eden ayrı bir şuur faaliyeti zannedişimizdir. Yaratma ameliyesi yekpare, spontane ve kendi tekniğini haizdir. Tashih etmek bozmaktan başka bir şey olmaz" (Safa, 2019: 95). Sanat eserinin kendine özgü tekniğini yaratma sürecinde belirleyeceği ve romanın belirli kurallarla yazılamayacağı düşüncesi, postmodern yazın alanındaki sınırsız özgürlüğün ifadesidir. Her romanında kendini aşmaya çalışan Safa'nın bu görüşlerinden yıllar sonra Robbe-Grillet; "Yeni roman, romanın sürekli bir geliş̧imidir" ve "her kitabın sadece kendisi için geçerli kuralları yaratabileceği" ni ifade eder (Baldıran, 2002: 7). Safa'nın romanın daimî bir "oluş" halinde olduğu görüşü, postmodern yazının öncülü Grillet'in anlayışıyla paralellik göstermektedir. Safa'nın yaratma sürecinde kendini özgür hissettiği, tek doğrunun ve yönelimin peşinde olmadığı, farklı olanaklara dikkat çekmek istediği görülür. Safa'nın yaratma sürecinin çeşitliliklerine yönelik tavrı ile okurun metne alımlayarak yaklaşımı, özünde postmodern anlatı dünyasının sınırsızlığına işaret etmektedir. Bu anlamda bu çalışmada amaçlanan, romanın postmodern roman olup olmadığını tartışmak değildir. Nitekim böyle bir tavır, postmodernizmin kategorize etmeyi dışlayan özüne bu tavır aykırıdır. Yazar-okur-metin ilişkisinin çok yönlülüğünü irdeleyen Peyami Safa'nın metninin mensubiyetini belirlemeye çalışmak da bu bağlamda yazarın hayatının merkezinde olan "yazı"ya adanmışlığını zedeler. Dikkat çekilecek nokta, Bir Tereddüdün Romanı'nın gerek içerik gerek kullanılan teknikler noktasında postmodern romana özgü olarak nitelenen bazı özellikleri bünyesinde barındırdığıdır. Günümüz için geçerli olan bu çıkarım, yıllar sonra farklı yorumlarla zenginleşecektir. Nitekim "zaman değisstikçe, çağ değiştikçe yapıt da hep değişime uğrayacak, iletisi farklllaşacak, yeni yeni uyarılara açı olacak ve yeni anlamlar üretecektir" (Özbek, 2005: 26). Bu anlamda bu çalışma, esere yönelik bir okuma, yorumlama, çözümleme denemesidir.

\section{Roman Kurgusunun Değerlendirilmesi}

"Tashih etmek bozmaktan başka bir şey olmaz"**

Roman, Muharrir ve iki okuru Muallâ ile Vildan arasındaki ilişki çerçevesinde kurgulanmıştır. Roman yazarı Muharrir'in Bir Adamın Hayatı adlı romanını okuyan Muallâ ve Vildan, Tanzimat romanından itibaren kullanılan "romanesk kadın" (Gürbilek, 2010: 25) karakterler olarak eserin aşırı etkilenen okurlarıdır ve bu anlamda kadın okurun etkilenmiş̧liği, roman kurgusunun esasını oluşturmaktadır. Roman kurgusunu şekillendiren okur-Muharrir ilişkisi, Muharrir'in 1. ve 3. şahıs anlatıcıların olduğu çoğul bakış açısının kullanımıyla sürdürülür. Muallâ’nın ilk bölümde okuduğu kitapla ilişkili yaşadığı deneyim, 3. şahıs anlatıcı tarafından aktarılır. İkinci bölüm, roman içindeki romanın yazarı Muharrir'in anlatıcı bakış açısıyla aktarılır. $\mathrm{Bu}$ bölümde Muharrir'in Muallâ'ya evlilik teklif etmesi, hayatına dair bilgiler ve düşünce dünyası otobiyografik tarzda yazar-anlatıcı tarafından aktarılır. "Yaşananlarla eser arasında çok yönlü ve kompleks bir

** Peyami Safa, Bir Tereddüdün Romanı, Ötüken Yayınları, İstanbul, 2019, s.95. 
ilişkinin kurulduğu üst kurmaca" (Eliuz, 2016: 116) metinde Muharrir, romanın karakterlerinden biri olarak kurgunun kendine ait kısımlarını anlatırken "fiziksel ve içsel bir yolculuk" (Eliuz, 2016: 116) yapmaktadır. Bu yolculuk imgesi, üst kurmaca metnin özellikleriyle inşa edilir.

Bir Adamın Hayatı romanının Muallâ tarafından hangi hislerle okunduğuna dair okurunu bilgilendiren yazar, ikinci bölüme; "BEN KI “Bir Adamın Hayatı” muharririyim, kitabımın etrafinda cereyan eden bu şeylerden hiç haberim olmadan ve Muallâ Hanım isminde hiç kimseyi tanımadan, bir Cuma günü dostum Raif'in apartmanına gittim" (Safa, 2019: 32) sözleriyle başlar. Bu giriş cümlesi, postmodern roman yazarının okuru metne dâhil etmesiyle, yazma sürecine aktif katılımını sağlaması bakımından benzerlik göstermektedir. Çünkü postmodern romanda "Yazar/anlatıcı meta düzlemden okura seslenir, kurmaca düzleme çekilen okurla metnin kurgulanışı üzerine söyleşi yapar” (Eliuz, 2016: 115). Böylesi bir okura sesleniş ilk roman örneklerinde de görülebilmektedir. Örneğin Ahmet Mithat Efendi’nin Müşâhedât romanının Berna Moran tarafından yeni tarz bir roman olduğu görüşü (Moran, 2001: 59), postmodern romanın nitelikleriyle bağdaştırılmaktadır. Fakat Ahmet Mithat Efendi'nin roman yazmasındaki ve bu tarzı kullanmasındaki niyetinin öğretici unsurları barındırması, bu çıkarımın tartışılması gereken bir mesele olduğunu ortaya koyar. ${ }^{1}$ Buna karşılık Safa'nın Batı'da ortaya çıkan yeni roman tekniklerinden haberdar olması, teknik üzerine düşünmesi ve kendisiyle yapılan söyleşilerdeki görüşlerinden yola çıkarak onun bu yöntemi bilinçli fakat acemice kullandığı söylenebilir.

İkinci bölümde Muharrir, yeni tanışmalarına rağmen Muallâ’ya evlilik teklif eder. Roman kurgusunu zayıflattığı düşünülen bu kısımda yazarın kurmaca içinde bir kurmaca yaratma iştiyakı hissedilir. Nitekim evlilik teklif etmeye gittiği anda hâletiruhiyesini aktardığı kısımda anlatı dünyasına özgü “oyunsuluk” (Ecevit, 2011:71) dikkati çeker. Bir varoluş, kendini gerçekleştirme biçimi olarak tanımlanacak oyun hayatı kurucu niteliğini barındırması bakımından varoluşsal bir eyleyiş tarzıdır; "İnsanın deneyimsel varoluşunun tamamı oyun oynama temeli üzerine inşa edilir" (Winnicot, 2013: 87). Dolayısıyla yazınsal alanda kelimeleri kullanış biçimi ile şiir metninde; hem kelimeleri hem kurgunun işlevini yönlendiren etkisiyle anlatı dünyasında oyun, yazara çeşitli imkânlar sunar ve yazım sürecini zevkli hale getirir. Muharrir, Muallâ’ya evlilik teklifini çeşitli tereddütler içerisinde çırpınan ruhunun kendine bir meşgale aramak iştiyakıyla ve bu zıtlıklardan "yeni bir terkip ve sistem çıkarmak için, yeni bir zekâ oyunu sarhoşluğu içinde oyalan”arak (Safa, 2019: 36) yapacağını belirtir. Fransızca bir metinden alıntılarla yönlendirdiği ruh hâli, onu evlilik teklifine hazırlar. Evlilik teklifinin ona yeni hikâye kapısı açtığına dair olan şu ifadeleri okuru, roman içindeki kurmaca dünyanın yazım sürecine dikkat çekmesi bakımından düşünceye sevk eder; "Bir evlenmek hikâyesi her şeyden evvel bana yeni sistemler aramanın taze ihtirasını vadettiği için ehemmiyetli ve güzeldi. Sayısız imkân ve âlemlerine doğru yapacağım hayalî seyahatlerin ümidi ve keyfi içinde öteki salona girdim... " (Safa, 2019: 36). Muharrir' in hikâye ve hayalî seyahatler ifadeleri, okuru davet ettiği kurmaca metnin dünyasıdır. Evlilik düşüncesi, yazarda yeni bir hikâye yaratma, hayali bir dünya kurma fikrini perçinlediği için kurmaca metnin iskeletine yerleşen bir vaka işlevindedir. Nitekim yazarın evlilik kurumuna ait görüşlerini ortaya koyması bakımından Muallâ'nın başrolünde olduğu vaka halkası, Muharrir'in ifade ettiği üzere araç konumundadır.

Raif'in evinde toplanan arkadaşlarıyla evlilik üzerine sohbetleri sırasında Muallâ ile tanışan Muharrir, okurunun Bir Adamın Hayatı romanıyla ilgili fikirlerini merak eder. Okur-yazar-eser ilişkisinin irdelendiği bu bölümde metnin üst kurmaca dünyasına dikkat çeken önemli bir ayrıntı söz konusudur. Muharrir, okur-yazar münasebetini ele alan bir roman yazma fikri üzerine düşüncelerini söylerken bulunulan anda bir roman vakasının başladığını belirtir; "Muharrir ile kari arasındaki meçhul ve karanlık münasebeti aydınlatacak olan böyle bir kitap yazmayı evvelce çok düşünmüştüm. Mecliste Raif'le benden başka hiç kimse böyle bir roman vakasının yarım saatten beri başlamış olduğunu bilmiyordu. Muallâ Hanım da, kendisinin haberi olmadan çekilen bir filmde en mühim rolü oynadı̆̆ının farkında değildi” (Safa, 2019: 46). Muharrir'in romanın vakasının başlangıcı ve seyri hakkında bilgi vermesi, okurun kurmaca metin içerisinde olduğuna dikkat çekmesi, roman ve roman içindeki romanın da aynı yazar tarafından kaleme alınması bakımından üst kurmaca metni düşündürür. Çünkü “Roman teorisinin metin yazma pratiği ile sentezlenmesi olan üstkurmacada anlatıcı da, açık bir şekilde ortadadır ve metnin kurmaca olduğunu metnin içine girerek gösterir” (Eliuz, 2016: 115).

\footnotetext{
1 Bu konuda ayrıntılı bilgi için bkz. Gökhan Tunç, "Müşâhedât Postmodern Bir Roman mı?”, Türklük Bilimi Araştırmaları (TÜBAR), Y11 13, S.24, 2008, s.239-250.
} 
Bir Tereddüdün Romanı'nda yazar, başkarakterdir ve karakter olarak yer alırken diğer karakterlerin durumu ve kurgunun şekilleniş süreci hakkında okurunu bilgilendirir. Muallâ'ya evlenme teklifi etmek için buluşmaya karar veren yazarın; "Kitabımla bir kadın kari arasındaki münasebet, böylece daha canlı ve mücessem bir hale geliyordu" (Safa, 2019: 50) sözlerinde üstkurmacaya ait gerçeklik-kurgu ilişkisindeki belirsizlik hâkimdir. Muharrir'in eski ve yeni ailelerin hususiyetlerini kendinde toplayan Muallâ karakterini kendisinin muhayyilesinde yarattığını, bu imkânsız tasarımın onda bir oyun oynama zevkine dönüştüğünü belirten ifadeleri, kurgunun "anlatıda metin aracllğglyla oynanan bilmecemsi/bulmacamsı bir oyun"a (Ecevit, 2011: 74) dönüş̧üğünü imler. Muharrir; "Zevcemi ben yaratmak istiyordum ve onun ayaklarl yeryüzüne basmayan hayali bir mahlûk olduğunu anlayacağım güne kadar, kendi kendime icat ettiğim bir kukla ile oynamak istedim" der (Safa, 2019: 49). Romanda dikkat çeken nokta, yazarın sözünü ettiği hayalindeki Muallâ ile karakter Muallâ'nın esasında aynı kişiler olmasıdır. Muallâ'nın romanı okumaya devam ettiği üçüncü bölümde ise karakterin kurmaca metindeki yerini sorgulayan yönüne işaret eden analizlerle karşılaşıllır. Anlatıcı, Muallâ’nın kendini okuduğu romanın bir karakteri sandığını, yaşadıklarını romandaki olaylarla bağdaştırmaya çalıştığını aktarır (Safa, 2019: 63). Muallâ kendisini roman karakteri olarak hayal etmesine rağmen, metin içerisine Vildan kadar nüfuz ettirilmez. Muallâ ile ilişkisinde onu sadece kurguyu yönlendirmek için kukla gibi kullanması, ona fazla söz hakkı vermemesi ve Vildan'ı ortaya çıkarmak için kurgulanmış bir karakter misali romanın seyrinde silik bir şekilde ortadan kayboluşu, romandaki dünyanın kurmaca oluşunun metinde vurgulanışıla netlik kazanır.

Muharrir'in hayatını ele alan iki romanın metinde birbiri içine geçmesi, postmodern romanlardaki gibi üstkurmacanın karmaşasıyla okuru yüzleştirmez. Bu yöntemi Safa'nın bilinçli olarak yeni deneyimliyor olması sebebiyle iki kurgunun birbiriyle ilintisinde bir kaos ortamıyla karşılaşılmaz. Postmodernist romanda yazma eylemi ile yaşama eyleminin birlikte yer aldığı (Sazyek, 2017: 605) düşüncesinin tam tersine, romanda Vildan tarafından "Çıplakları Giydirmek" piyesinden bir alıntıyla dikkat çekilir. "Bir roman ya yazılır, ya yaşanır" (Safa, 2019: 111) ifadesi esasında Muharrir'in ikisi arasındaki tereddüdünü imler. Dolayısıly metninde gerçeklik-kurgu çatışmasını yazar-anlatııını iki roman metnindeki ilişkiler paralelinde ele aldığı görülür. Romanın üst kurmaca niteliğine başka bir örnek ise Vildan ile münasebetlerinin başladığı bölümde yer alır.

Okuduğu eserlerin etkisinde kalan Vildan, "tipik bir bovaristtir" (Gürbilek, 2010: 27). Kadının kitapla ilişkisinin ruhen ve bedenen yarattığı infialin örneği olarak gösterilebilecek Vildan, okuduğu romanları yaşaması bağlamında Muharrir'in aynı zamanda hem çekindiği, uzaklaşmak istediği hem de dikkate almaktan kendini alamadığı yönüyle yazara üst kurmaca tekniği en iyi uygulatabileceği karakterdir. İstanbul'a yazarını aramaya gelen Vildan, "Mümkün olduğu kadar az vakası olan kitap ve hayat"ın (Safa, 2019:103) peşindedir. Postmodern romanlarda görülen yolculuk, arama, macera metaforlarıly ilişkilendirilebilecek bu durumun neticesinde Vildan, istediği kurgunun içerisinde yer alırken romanlarıyla hayalini kurduğu Muharrir' in yanında bulunur. Muharrir'in "romanesk bir cinayet yapmak isteyen bir hayalperest" (Safa, 2019: 139) olarak tanımladığı Vildan, Muharrir'i evine davet ettiğinde intihar girişimini ve yazarı öldürmeyi düşündüğünü itiraf eder. Bu noktada yazar, "okura acaba Muharrir'i öldürecek mi?" diye düşündürür. Okuduğu romanları yaşamaya çalışan Vildan, gerçeklik-kurgu çatışmasını eylemlerinde yansıtmaktadır. Bu bölümde üst kurmaca olarak nitelendirilecek bir nokta da mekânların iki romanda da ortak olarak kullanılmasıdır. Metinlerdeki ortak mekânlar, Vildan'ın Muharrir'le buluştuklarında gittikleri Hürriyet Tepesi ve dükkân aynı fonksiyonlarıla Bir Tereddüdün Romanı'nda yer alır. Dolayısıyla yazar, okuru Vildan'a, hayal ettiği roman dünyasını yaşatır. Böylelikle romanda yaşamla kurgunun otobiyografik düzlemde tasarlandığı dikkat çeker.

Postmodern romanın kurguyu şekillendiren, destekleyen, renklendiren yöntemlerinden biri de metinlerarasılıktır. Tür ayrımı yapmadan farklı metinlerin bir arada kullanıldığı, metinlerden alınan parçaların anlatı metnine yerleştirildiği ve böylece metnin kurgusunun dönüştürüldüğü, alınan metnin yeniden oluşturulduğu yöntemde "üslup, konu, anlatım biçimi" birleştirilir (Eliuz, 2016: 121). Postmodernizmin hem parçalayan hem bütünleyen bakış açısına uygun bir yöntem olarak geleneksel bütün metinleri bozma, hedefini kaybetme bağlamında eleştiri alırken metinlere yönelik bir ayrımın olmaması, seçkinciliği bertaraf edip her üretimi dikkate alması bakımından da onanabilmektedir. Safa, bütün romanlarında olduğu gibi Bir Tereddüdün Romanı'nda da bu yöntemi alıntı, gizli alıntı, anıştırma ve palimpsest biçimlerinde kullanmıştır. Farklı yazarların metinleriyle birlikte Safa'nın kendi roman metinleri arasında da metinlerarasılık yöntemini 
kullandığı görülür. ${ }^{2}$ Pirandello'nun Çıplakları Giydirmek piyesi ve Feu Mathias Pascal romanı; Necip Fazıl'ın Kaldırımlar ve Otel Odaları şiirleri; Namık Kemal'in Kitalar' 1 ; Vagner, Werther, Shakespeare'in Makbet ve Hamlet oyunları, Victor Hugo, ilk bohem Henri Murger, Napoleon, Pierre Loti, Oscar Wilde, Andre Gide, Karl Marx, Baudelarie, Nietzsche, Eflâtun, Ömer Hayyam, Gazali, Dostoyevski, Freud, Giftos Karpantiye karakteri romanda metinlerarasılık yönteminin çeşitli şekillerinde kullanılmıştır.

Yapıtların farklı yorumlamalara açık olduğunu disiplinler arası bağlamda kritik ettiği Açı Yapıt adlı eserinde Umberto Eco; "Bir kitap ne başlar ne biter, olsa olsa öyle gibi görünür" (Eco, 1992: 23) olduğunu belirtir. Poetikanın sınırsızlığının da ortaya konduğu bu görüşle roman metninin bitmeyen kurgusu açıklanabilir. Hem Bir Tereddüdün Romanı hem de içerisindeki Bir Adamın Hayatı romanı, sonlarının belirsiz olması noktasında açık yapıt örneğidir. Safa Bir Tereddüdün Romanı'nı vaazla bitirmesine rağmen, okurun zihninde tamamlanmamışlık hissini bıraktığı için yoruma açıktır. Romanın kurgusunu yönlendiren Bir Adamın Hayatı romanı ise Muallâ'nın rastgele okuyuşları neticesinde okurda parçalı algılama kabiliyetini perçinler. Roman içerisinde romanın okunma süreci ve romanın sonunun tamamlanmasında okurun aktif olması gerekmektedir. Safa'nın garp edebiyatında olduğunu belirttiği gibi mevzusu olmayan, kronolojik olarak ilerlemeyen bir sonuca bağlanmayan roman (Safa, 2012: 201), metinde tüketim sürecinin asıl yaratıcı süreç olduğu alımlama estetiğinin yaklaşımını destekler (Özbek, 2005: 13). Bir Adamın Hayatı'nın eksik olduğunu belirten Muharrir'e Vildan; "Okuyanlar eksikleri tamamlarlar" der. Muharrir 'in buna karşılık verdiği "Kendilerine göre. Ne ise, geçelim bunu" (Safa, 2019: 116) ifadeleri romanın üretiminin okuma sürecinde de devam ettiğine işaret eder. Dolayısıyla Bir Adamın Hayatı romanına dair Muharrir ile Vildan'ın konuşmalarında "yaratıcılı̆̆ın önünü açmak, tüketiciyi aktif, üretici, yaratıcı" (Özbek, 2005: 25) hale getirmenin önemi dikkat çeker. Bu noktada Vildan ve Muallâ'nın okur olarak romandaki konumunun yazar tarafindan belirli bir kıyasa tabi tutulduğu söylenebilir. Böylece Safa, otobiyografik romanında Eco'nun kritik ettiği örnek okurunu arayan ampirik yazar gibidir. Romanı kurmanın, inşa etmenin, tasarımlamanın önemli olduğu (Ecevit, 2011: 45) postmodern roman yazarına uygun davranır. Muallâ, metne hazır olmayan, onda sadece "kendisiyle beraber yaşanacak sevimli bir arkadaş" (Safa, 2019: 23) arayan ampirik okurken³; Vildan, metne aktif katılan, metni üreten ve yazarın istediği metnin içine giren örnek okurdur. Eco'ya göre "örnek okur oyunda kalmayı bilen kimsedir" (Eco, 1995: 16) ve Vildan, Muharrir 'in oyununa romanda dâhil olur böylece oyunu romanın sonuna kadar onunla devam ettirir.

\section{Roman Karakterlerinin Postmodern Özne Bağlamında Değerlendirilmesi}

Farklı isimler kullanarak eserlerini yayımlayan Safa'nın bu denli çok isim kullanmasına rağmen otobiyografik tarzda yazdığı eserlerinde kendini temsil eden karakterlerin bir isminin olmaması, yazarın başkası olma iştiyakından, kendini çoğaltma veya silikleştirme isteğine kadar çok farklı şekillerde yorumlanabilir. Bu romandaki yazar özne olan Muharrir'in de romanda bir ismi yoktur. Yazar öznenin kendini roman kurgusundaki kişiliklerle yeniden kurma tavrı, bütün edebî türlerde veya sanatsal eserlerde söz konusudur. Romanın yazara sunduğu çok kişilikli, kimlikli olma olanağı, her dönemin edebî ürünlerinde ele alınabilecek bir yönelimken postmodern türlerde çoklu söylemin ve kişiliklerin varlığı etkindir. Yaşamsal ve zihinsel kavrama alanını her edebî metninde yeniden kuran Safa'nın birçok roman karakteri kendinin çoğaltılarak yeniden oluşturulmuş, dönüştürülmüş şekilleridir. Safa, otobiyografik romanın yaratma sınırını kısıtlaması sebebiyle başka dünyalardaki farklı tecrübe ve serüvenlerden yararlandığını belirtir (Baydar, 2015: 258). Geleneksel metinlerdeki kahramanların yerini "bir adamın hayatındaki şahsiyet krizlerinin ve büyük deruni faciaların" (Safa, 2012: 211-212) ve insan ruhunun almasıyla romanın değişen öznesine dikkat çeker. Yazar öznenin kendini tanıması, sorgulaması, varoluşunu yazınsal alanda ortaya koyması, kendinden yola çıkarak

\footnotetext{
${ }^{2}$ Bir Tereddüdün Romanı'nın metinlerarası bağlamı konusunda ayrıntılı bilgi için bkz. Cemile Kaygısız, "Bir Tereddüdün Romanı"na Metinlerarasılık Bağlamında Peyami Safa'nın Hayatı ve Eserleri Üzerinden Bakmak”, Uluslararası Sosyal ve Ekonomik Bilimler Dergisi, 1 (2), 2011, s. 35-38; Can Şen, “Bir Tereddüdün Romanı'nın İtalyan Misafiri: Luigi Pirandello”, Hece Dergisi Peyami Safa Özel Sayısı, S. 217, 2015, s. 380-390.

${ }^{3}$ Muallâ'nın romandan aşırı etkilenmesi klasik kadın okur tavrıdır. Okuma süreci ilerledikçe vakayı değil de insanın ruhunu gözlemleyen okur olması anlamında örnek okur gibi değerlendirilebilirse de yazar onunla istediği eser-okur-yazar ilişkisini kurmaz.
} 
yarattı̆̆ı karakterlerle gerçekleşir. "Her roman kahramanı romancının içindeki sayısız şahsiyet imkânlarından birinin yumurtasindan firlamıştır" (Safa, 2012: 225) görüşüyle Safa, roman karakterlerini muhayyilesinden yarattığını, inşa ettiğini ortaya koyar. Bir Tereddüdün Romanı ve Bir Adamın Hayatı romanlarının Muharrir’i şahsiyetinin zıt yönlerini tereddüt kavramı etrafında kurar. Roman karakterlerinden Muallâ, yazarın idealist yönünü temsil ederken; Vildan, karakterinin “arızalı, tereddütlü” yönünü karşılar. Gürbilek'e göre Safa'nın “ "ideal yazar" olabilmek için saf dışı etmesi gereken gizli ikizi" (Gürbilek, 2020: 152) Vildan, yazarın karanlık yönüdür. Dolayısıyla yazar özne hep kendini arayan ama bu arayışta ötekilere bağlllık duyan, sanatkâr olarak eserinin kurgusuna yabancılaşırken kendine dönüşün de yollarını arayan parçalanmış öznedir. Yazar özne, romandaki öteki-benleriyle çoğalırken onlarla kendini de bütünlemek ister. Vildan'ı romanın sonunda ortadan kaldırarak ve onunla ilişkisi bağlamında bütün tereddütlerinden arınmak ister. Yazar, parçalı benliğinin eksik yönlerinden, arızalı yönlerinden "şeytan çıkarırmış gibi" (Gürbilek, 2020:153) kurtularak "ulusal alegori kadar cinsel alegori üzerine de kurulu bir "kendi" kalma savaşını" (Gürbilek, 2010: 178) verir. Safa özelinde bu savaş, hegemonik anlamda "eril kalma mücadelesi”dir (Gürbilek, 2010: 178). Safa'nın kadın-erkek kimliğinin toplumsal alandaki konumlarını irdelerken oyunu erillikten yana kullanması, bu romanda da söz konusudur. Dolayısıyla yazar özne kendini her metinde çoğaltarak yeniden inşa eder, dönüştürür. İki romanın kahramanı Muharrir, "bohem-nihilist-Vildan'sı ikizini, “yalnzzlı, hastallk, nöbet ve ölüm titremelerinin yazarını"” (Gürbilek, 2020:153) Bir Tereddüdün Romanı'nda ortadan kaldırır. Böylece Muharrir, kendini Vildan ile çoğaltır ve Vildan roman boyunca yazar öznenin yazıda varoluş sürecine kaynaklık eder. Yazar öznenin kendini kurguladığı karakterlerle çoğaltması, var olma çabasının farklı görünümleridir. Nitekim Vildan da okuduğu karakterlerle kendini özdeşleştiren, varlığını başkalarıyla anlamlandırmaya çalışan, ötekilerle kendini tanımlarken bir yandan da çoğaltarak ruhunu didikleyen bir karakterdir. Gürbilek'in Safa'nın ikizi olarak tanımladığı Vildan, değişimden korkmayan bilakis kendini değişmeye farklı benliklerde soluklanarak adayan bir karakter olarak konumlanır. Muharrir'e "Kendi haline kalırsan nesin sen? Bu kuvveti almak için benim hayalime ihtiyacın var. Kendini benim dev hayalimin dev aynasinda görerek mağrur oluyorsun sen..."der (Safa, 2019: 105). Dolayısıyla yazarın içindeki ben'in karaktere dönüşmüş hali gibi serzenişlerinde eril gücün söze hükmü dikkat çeker. Kimi zaman Vildan'ın sesinde eril söylem belirir. Muharrir 'in "Hayret! Hayret! Münevver bir Türk ve Müslüman erkeği gibi konuşuyorsun. Bütün tabirleri ve istılahları biliyorsun" (Safa, 2019: 174) ifadeleri de bu duruma dikkat çeker. Vildan, Muharrir'in kurguladığı, kendi içinden türemiş ve romanda bazen kendini yazarın iç sesinden yazara karşı savunan karakter olarak yer alır. Postmodern öznenin cinsel kimliğe yönelik belirsiz içeriği bu anlamda Vildan'da yazar öznenin kendini parçalı kimlikle inşa edip yaşatmasıyla ortaya konulur. Nitekim Vildan, buluştuklarında "kendimizi kaybetmiştik, sen ikimizi de buldun" (Safa, 2019:174) sözleriyle de yazar öznenin yazıda benlik arayışının öteki ile gerçekleşeceğini imler. Romanda Vildan-Muharrir ilişkisi, özellikle Vildan'ın söylemsel konumu bağlamında efsunlu bir içeriğe sahiptir. Okuru düşündüren bu ilişki biçimi, Levinas'ın "başka ile ilişki gizem ile iliş̧kidir" (Levinas, 2005: 102) çıkarımında ifadesini bulur. Şaşırtmacalar romanın sonunda yazarın romanın temel izleğini sonuca bağlama tavriyla da son bulmaz. Romanda kendine yol almak isteyen Vildan ve Muharrir'in ötekine yönelik eğilimlerinde sürekli bir kendi benliğine dönüş imgesi ile karşılaşllır. Her durumda "yepyeni bir insan" (Safa, 2019: 120) olduğunu keşfederek "insanda nâmütenahi şahsiyet imkânları"nı (Safa, 2019: 121) kullanırken dinamik bir ben-öteki ilişkisini yaşar/yaşatır. Kendisini dışarıdan seyretmek isteyen Muharrir'in gizli ikizi, böylesi bir parçalanmanın yarattığı infialle romanda yok edilir. Çünkü "kendisini seyretmekten yorulunca ölürmüs bir oyuncu" (Ergülen, 2008: 52). Vildan, sonu bilinmeyen bir sonla yazarın kendini bağlı hissettiği değerler mekanizması için ortadan kaldırılır.

Vildan karakteri merkezinde parçalı postmodern özne kendini yitiriş, kaybediş ve köksüzlük, yurtsuzluk olarak kurgulanır. Vildan, “ulusal köklerinden kopmakla kalmayıp ego sınırlarını da yitirmiş" (Gürbilek, 2010: 27) bir nihilist özne örneğidir. Anlam sorgulamalarının bir neticeye ulaşmadığı Vildan, romanda yalanlarıyla da olsa insana ait zıtlıklardan şekillenmiş dinamik bir var oluş-yok oluş diyalektiğini okurlara her anında yaşatır. Romanın ana izleği tereddüt düşüncesini her haliyle yansıtmaktadır. Modern dönemin bir kimliğe ait olma düşüncesi, postmodern dönemde kimliksizleşme olarak ortaya çıkar. Vildan'ın konumu bu anlamda kendi kimlik değerlerine yerleşememiş, bilinç bulanıklığını başkası olmakla onarmaya çalışan ve neticede nereye ait olduğu belirsiz bir merkezsizliğe yol alır. Sabırsız, bir yere sığamayan, tez canl, kendini gizemli hale getiren, her şeye alakasını kaybetmiş, her durumda yeni bir şahsiyete bürünen, esasında çıplaklık hissiyle boğuşan, 
kendinden kaçtıkça nefretle kendine dönen, zihinsel ve fiziksel olarak yerleşikliğe uzak, benlik yitimine uğramış, ait olma korkusuyla savrulan parçalı postmodern özne örneğidir. Her durakta hazzı ölçüsünde duran Vildan, Muharrir'e göre hiçbir durumu tam anlamıyla yaşayamamıştır. Bu yerleşik olmama durumu, öznelerde her türlü bağımlılıktan kurtulmaya çalışma, aile, toplum hayatından uzaklaşma, mesuliyet bilincini reddetme, boşluk ve hiçlik hissi ile çağa özgü problemleri aşılamadığı için sürekli bir sığınak arayışı olarak görülür. Nitekim Vildan karakteri Nietzsche'nin postmodern öznenin oluşumunun sinyallerini verdiği insanı ve onun toplum içerisindeki gayesizliğini irdelediği insanı yansıtmaktadır. Nietzsche insanın aydınlanma süreci sonrası idealleştirilemediğine ve böylece yıkımın, savaşın, barbarlığın aslında insanı soysuzlaştırdığına yönelik modern dönem eleştirisiyle nihilist karakterlerin oluştuğuna dikkat çeker. Nietzsche'ye göre "en üst değerlerin değersizleşmesi, hedef yok: "Niçin"e bir yanit verilebilmiş değil"dir (Nietzsche, 2002: 23). Vildan'ın gayesinin, hedefinin olmadığına canının istediğini yapmaya özgür olduğuna dair görüşleri, bu anlamda değerlendirilmelidir. Romanın ana meselesi olarak irdelenen tereddüt, nihilist öznenin gayesizliğinin sebebidir. Romanın sonunda Muharrir'in geleneksel romanda hâkim olan anlatıcı figürün kuşatıcıllğıyla kontrolcü yazar gibi, modern düşüncenin, düşünürlerin insanlığa verdiği zarara yönelik çıkmazların analizini yaparak bir sonuca varmaya çalışsa da Vildan karakteri ile bir devir kapanmaz tam tersine açılır. 1918'den sonra insanlığın yaşadığı tereddüdün insanlığın değerlerinde yıkılışa sebep olmasını kabullenemeyen bir yazarın kontrolü ile karşılaşırız. Romanın savaş sonrası bireylerin yaşadığı bunalımı ele alması, Tonybee'nin "Postmodern çağın belirgin özelliği, büyük savaşlar, devrimler ve karmaşadır" (Şeylan, 2009: 37) görüşünden yola çıkarak açıklanabilir. Böylece roman karakterlerinin yaşadığı bunalımın ve varoluşun anlamına dair sorgulamalarından hareketle irdelenen insanın postmodern döneme geçiş ürünü olduğu söylenebilir.

İstediğini yapan hazcı özne Vildan, modernleşme olgularının insanın yaşam koşullarını iyileştirmesine rağmen yaşamın ve dünyanın anlamını kaybetmesine sebep olduğu bireydir. Tapınacak bir şey arayan (Safa, 2019: 119) yurtsuz özne, amaçsızlığa ve ruhsal acıya maruz kalır. Bauman, özgürlüğün, kuşkunun, müphemliğin bir arada oluşunun yarattığı uyumsuzluğu şöyle ifade eder: "Katı olan her şey buharlaştıkça ve kutsal olan her şeyin kutsiyeti bozuldukça, modernite istekler ve yetenekler arasında sürekli bir uyumsuzluk çağına girdi" (Bauman, 2011: 77-78). Vildan tam olarak modern çağ sonrası belirsiz ve istikrarsız ortamın yarattığı çözülüşün temsilidir. Değerlerden çözülüş, yıkılış, Vildan'ın kendini mizantrop ${ }^{4}$ ve deracine ${ }^{5}$ olarak tanımlamasıyla sonuçlanır. Uyumsuz Vildan, hiçbir sınıfa dâhil olmak istemeyerek, Muharrir'in vaazından rahatsız olur. Kalıpları, katı olan her şeyi parçalamayı isterken zihni yol alışında geleneksel değerleri yıkıma uğratır. “ Tabiatlar, cemiyetler, anallklar, idealler, saadetler... Bu söylediğin şeyleri Incil de yazıyor, Kur'an da yazlyor" (Safa, 2019: 72) ifadeleriyle postmodern parçalı yersiz, yurtsuz özneyi işaret eder. Kendini tanımlamaktan, imzasını atmaktan, belirli bir kimliğe dâhil olmaktan ziyade Deleuze'ün çınarın karşısına koyduğu köksüz "rizom (köksap)" örneğini yansıtır. Çokluğun, dağınıklığın ve bireyselliğin olduğu heterojen yapıda "Köksap bilgisi, köklerin ve temellerin kökünü kazımaya, birlikleri bozmaya ve ikilikleri alaşağı etmeye ve kökleri ve dallarl dağıtmaya, farkllllklar ve çok katlllklar üreterek, yeni bağlantılar kurarak, çoğullaş̧tırmaya ve sirayet etmeye çalışır" (Kaya, 2014: 281). Vildan'ın kendiyle birlikte birçok değere yönelik ortadan kaldırış tavrı bu anlamda Deleuze'ün göçebe, yerleşemeyen öznesine örnek verilebilir. Herhangi bir durumu köklerinden kopararak an'a yönelik yorumlama, bilgiyi, hazzı göçebelikle elde etme, Kültürel bağlarından, kökensel bağlarından nefret eden, dünyanın toprağından kopan (Safa, 2019: 125) Vildan'ın karakteristik özelliğidir.

Bir Adamın Hayatı'nda yer alan entelektüellerin konumu da yurtsuz göçebelikle bağdaştırılabilir. Toplumsal baskılardan her türlü siyasal, toplumsal iktidar odağından kaçış alanları oluşturmaya çalışan grup, değer yitirme endişesini de taşırken hedeflerinden uzaklaşmış kayıp entelektüeller gibidir. An'ı yaşama iştiyakında hedonist, karmaşık zihinli, kendi olamayan, madde bağımlısı, böylelikle hayatta gerçeklikten koparak kendilerine özgürlük alanı oluşturmaya çalışan parçalı göçebe yurtsuz özne örneğini yansıtırlar. Kesinlikle düzeni değiştirme dertleri olmayan ve doğal akışta kendilerine arzularını dolaşıma sokacakları ortamlar oluşturan bohem karakterlerdir. Tek tutundukları nokta bohem yaşantıları ve entelektüel birikimleri olan bu grup da romanda dönemlerine yönelik inançsızlıklarıyla yer alır. Hürriyete ve demokrasiye iştiyakları yazarın

\footnotetext{
${ }^{4}$ Mizantrop: İnsanlardan nefret eden, toplumdan ve insanlardan kaçan.

${ }^{5}$ Deracine: Kökünden kopmuş.
} 
metinlerarasılık yöntemiyle söz ettiği "kaldırım çocukları" (Safa, 2019: 90) bölümünde aktarılır. Kaldırımlarda gece özgürlüğünü arama bu anlamda her türlü otoriteden kaçan yersiz yurtsuz ve parçalı öznenin işaretidir. "Sahte ciddiyetleri parçalama" ve "kabuktan şahsiyetler"inden kurtularak "samimi, hakiki ve dinamik yaşam" elde edeceklerini düşünürler. (Safa, 2019: 81) Deleuze'ün arzunun üretimi olarak kavramsallaştırdığı olumlu anlamda içeriklendirdiği görüşten yola çıkarak, gayeden nefret eden sadece arzularının akışıyla hayatın dinamik akışına katkıda bulundukların iddia eden bireyler oldukları söylenebilir. İktidar odaklarından kaçarak "kendi muhtariyetini arayan münevverler aşireti”" (Safa, 2019: 90) kendi kurdukları düzende özgürlüklerini yaşamak isterler.

Muharrir romanın ana matrisini ve karakterleri kritik ettiği son kısımda, iki dünya savaşının yarattığı bireysel ve toplumsal tahribatın farklı bir noktaya gelip dayandığını ve modernliğin sunduğu imkânların arızalı yönlerinin ortadan kalktığını belirtir. Klasik olandan istifade etmeyen modernitenin getirdiği sistemlerin bireyleri "Hayatın sonsuz değişmelerine intibaktan" (Safa, 2019: 94) yoksun bırakarak, insanları yaratıcılıktan uzaklaştırarak "Weber'in 'demir kafes' adın verdiği gayri şahsi mekanizmalar”a (Taylor, 1995: 15) hapsettiğini belirtir. Sistemcilik, izm'ler, nazariyecilik sürekli akış halinde olan hayatı statikleştirmeye, dondurmaya, kalıplamaya çalışır. Özünde sürekli değişimin, başkalaşımın olduğu hayatın yerine insanların kalıplaştırıldığı dünyada insanlığın yaşadığı tereddüdü Avrupa düşüncesi merkezinde sorgular. Hayatın barındırdığı dinamik varoluş sürecinin ancak sezişimizle açıklayabilme düşüncesi dolayısıyla gelecek tasarımının değil an'ın odağında bir yaşam biçimi postmodern düşünürlerin etkilendiği Bergson'un zaman anlayışıyla örtüşür. Muharrir' in komünizm ve kapitalizmin sonunun geldiği ve yeni bir devrin açıldığı görüşleri de aynı şekilde postmodernizmde karşıllı̆ını bulacak yenidünya anlayışını imler. Dolayısıyla Muharrir, roman sonu vaazıyla "postmodern sayılan tutum, üst-anlatılara karşı inançsızlıktır" (Lyotard, 2013: 8) düşüncesinin kritiğini yapar. Vildan'ın her şeyin yıkıldığı görüşüne karşılık her şeyin başkalaştı̆̆g, sallandığ $l$ sloganı da bu anlamda değerlendirilmelidir.

\section{Sonuç}

Roman türü hususunda çeşitli değerlendirmeler yapan Safa, bizzat eserlerinde 'mükemmel"e ulaşmak gayesiyle çeşitli teknikleri dener. Romanın ulusal ve uluslararası bağlamda geçirdiği dönüşümlere dikkat kesilen Safa'nın Bir Tereddüdün Romanı'nda kurguyu şekillendiren teknikler ve karakterlerin konumu noktasında postmodern romana özgü nitelikleri kullandığı dikkat çeker. Romanın içinde bulunan Bir Adamın Hayatı romanıyla ilişkide üst kurmaca tekniğinin ve çeşitli şekillerde metinlerarasılık yönteminin kullanılması, yazar-okur-metin ilişkisinin roman yazma süreci bağlamında kurgulanması, çoğul bakış açısıyla metnin kaleme alınması, okurun metne dâhil edilmesi, yazarın okurla söyleşmesi, roman içerisinde bir roman yazma sürecinin yer alması ve başka bir romanın ana metnin kurgusunu şekillendirmesi postmodern roman özelliklerini yansıtmaktadır. İki romanın başkarakterinin isminin olmayışı ve iki romanın sonunun tamamlanmayıp, okurun yorumuna bırakılması açık yapıt olarak değerlendirilebilir. Roman karakterleri, yazarın içinden çoğaltılarak inşa edilmesi ve kendindeki zıtlıkların bütünleyicisi olarak yer almaları bakımından parçalı benliğinin görünümleridir. Muharrir'in kendini inşa ettiği okuru Vildan, parçalı, köksüz, yurtsuz, gayesiz oluşuyla, tutunma ve inanma ihtiyacını karşılamak için çırpınan, benlik yitimine uğramış, her türlü bağımlılıktan kurtulmaya çalışan parçalı postmodern öznedir. Bir Adamın Hayatı romanındaki entelektüel grubu da parçalı, yurtsuz, kimlik karmaşası yaşayan, toplumsal baskılardan kaçarak özgürlük alanları oluşturmaya çalışan, hedeflerinden uzaklaşmış postmodern parçalı, göçebe özneye dâhil edilebilir.

20. yüzyılın son devrelerinde Türkiye'de ortaya çıkan postmodern yazın öncesi bilinçli veya bilinçsiz çeşitli örnekler dikkat çeker. Bu anlamda postmodern yazın unsurlarını Peyami Safa'nın romanlarında görebilmek mümkündür. Yapılan tespitlerden yola çıkarak Bir Tereddüdün Romanı, Şaban Sağlık'ın postmodernizmin Türkiye'de varoluş evrelerinden ikincisi olarak belirttiği “'Post'suz Postmodernizm Yahut Erken Postmodernizm" (Sağlık, 2017: 80) grubuna dâhil edilebilir. Safa, romanda uyguladığı farklı tekniklerin ortaya çıkacak postmodern romanın özellikleri olduğunun/olacağının bilincinde değildir. Romanın unsurlarında Avrupa'da değişiklik olduğunun bilincindedir, insanlığın da bir kriz dönemi yaşadığını tereddüt kavramı etrafında sorgular; fakat bunların postmodernizmin dayanakları olması 20. yüzyılın ikinci yarısına tekabül eder. $\mathrm{Bu}$ anlamda modern ve postmodern anlayışın birbiri içinde yer aldığı-nitekim iki kavramın sınırları hala 
belirgin değildir- bir dönemde kaleme alınan eserin modernden postmoderne geçişte kritik evreyi yansıtan bir geçiş dönemi ürünü olduğu söylenebilir.

\section{Kaynakça}

Baldıran, G. (2002). Alain robbe- grillet ve yeni roman. Konya: Çizgi Kitabevi.

Bauman, Z. (2011). Bireyselleşmiş toplum. İstanbul: Ayrıntı Yay.

Baydar, M. (2015). Edebiyatçılarımız ne diyorlar? İstanbul: İletişim Yay.

Ecevit, Y. (2011). Türk romanında postmodernist açıllmlar. İstanbul: İletişim Yay.

Eco, U. (1992). Açık yapıt. (Çev. Yakup Şahan). İstanbul: Kabalcı Yay.

Eco, U. (1995). Anlatı ormanlarında gezinti. (Çev. Kemal Atakay). İstanbul: Can Yay.

Eco, U. (2003). Yorum ve aşırı yorum. (Çev. Kemal Atakay). İstanbul: Can Yay.

Eliuz, Ü. (2016). Oyunda oyun postmodern roman. İstanbul: Kesit Yay.

Ergülen, H. (2008). Hafiz ile semender toplu şiirler II. İstanbul: Turkuaz Kitap.

Gürbilek, N. (2020). Benden önce bir başkası. İstanbul: Metis Yay.

Gürbilek, N. (2010). Kör ayna, kayıp şark. İstanbul: Metis Yay.

Kaya, R. (2014). Post-anarşizmin sırt çantasındaki deleuze. Aytaç A. M., Demirtaş M. (Ed.). Deleuze Düşüncesinin Sinırlarında Göçebe Düşünmek içinde (ss. 256-291). İstanbul: Metis Yay.

Kaygısız, C. (2011). Bir Tereddüdün Romanı"na Metinlerarasılık Bağlamında Peyami Safa'nın Hayatı ve Eserleri Üzerinden Bakmak. Uluslararast Sosyal ve Ekonomik Bilimler Dergisi, 1 (2), 35-38.

Levinas, E. (2005). Zaman ve başka. (Çev. Özkan Gözel). İstanbul: Metis Yay.

Lyotard, J.F. (2013). Postmodern durum. (Çev. İsmet Birkan), Ankara: Bilgesu Yay.

Moran, B. (2001). Türk romanına eleştirel bir bakış 1, İstanbul: İletişim Yay.

Narl, M. (2012). Roman ne anlatır? cumhuriyet dönemi (1920-2000) türk romant üzerine tematik bir tasnif ve değerlendirme. Ankara: Akçağ Yay.

Nietzsche, F. (2002). Gü̈ istenci. (Çev. Sedat Umran). İstanbul: Birey Yay.

Özbek, Y. (2005). Postmodernizm ve alımlama estetiği. Konya: Çizgi Kitabevi.

Safa, P. (2019). Bir tereddüdün romanı. İstanbul: Ötüken Yay.

Safa, P. (2012). Sanat, edebiyat, tenkit, İstanbul: Ötüken Neşriyat.

Sağlık, Ş. (2017). Postmodernizmin Modern Türk Edebiyatındaki Üç Hali. Yüzüncü Yıl Üniversitesi Sosyal Bilimler Enstitüsü Dergisi. Türk Kültür Dünyası Özel Saylsı, I, 71-87.

Sazyek, H. (2017). Türk Romanında Postmodernist Yöntemler ve Yönelimler. Hece Türk Romanı Özel Saylsl, 2 (65-66-67), 599-620.

Şen, C. (2015). Bir Tereddüdün Romanı'nın İtalyan Misafiri: Luigi Pirandello. Hece Dergisi Peyami Safa Özel Saylsi, S. 217, 380-390.

Şeylan, G. (2009). Postmodernizm, Ankara: İmge Kitabevi.

Tarancı, C. S. (1940). Peyami safa hayatı ve eserleri. İstanbul: Semih Lütfi Kitabevi.

Taylor, C. (1995). Modernliğin sıkıntıları. (Çev. Uğur Canbilen). İstanbul: Ayrıntı Yay.

Tunç, G. (2008). Müşâhedât Postmodern Bir Roman mı? Türklük Bilimi Araştırmaları (TÜBAR), 13 (24), 239250.

Yavuz, H. (2010). Okuma biçimleri. İstanbul: Timaş Yay. 